\title{
The comparison of the perinatal outcomes in monochorionic twin pregnancies with and without selective intrauterine growth restriction
}

\author{
Elif Fide Pişirgen ${ }^{1}$ (D), Münip Akalın² (D), Oya Demirci ${ }^{2}$ (D), Pınar Kumru ${ }^{3}$ (D), Emine Eda Akalın ${ }^{4}$ (DD \\ ${ }^{1}$ Gynecology and Obstetrics Clinic, Şanluurfa Mebmet Akif Inan Training and Research Hospital, Şanhurfa, Turkey \\ ${ }_{2}^{2}$ Perinatology Clinic, Zeynep Kamil Maternity and Pediatrics Training and Research Hospital, İstanbul, Turkey \\ ${ }^{3}$ Gynecology and Obstetrics Clinic, Zeynep Kamil Maternity and Pediatrics Training and Research Hospital, İstanbul, Turkey \\ ${ }^{4}$ Gynecology and Obstetrics Clinic, Kartal Dr. Liitfi Kirdar Training and Research Hospital, Istanbul, Turkey
}

\begin{abstract}
Objective: Both fetuses may be affected negatively as a result of the non-equal share of the placenta and vascular anastomoses in monochorionic pregnancies with selective intrauterine growth restriction (sIUGR). In our study, we aimed to investigate the perinatal outcomes of both larger and smaller fetuses in monochorionic pregnancies with and without sIUGR (non-sIUGR) separately.

Methods: A total of 196 monochorionic twin pregnancies were evaluated retrospectively between January 2013 and January 2019. The cases were grouped as sIUGR and non-sIUGR pregnancies. The pregnancies with sIUGR were also separated into sub-groups as the cases with normal umbilical flow pattern and the cases with abnormal umbilical flow pattern. The perinatal outcomes were investigated separately between the groups for larger and smaller fetuses.

Results: Of 153 monochorionic pregnancies included in the study, $17.6 \%(\mathrm{n}=27)$ were sIUGR cases and $82.4 \%(\mathrm{n}=126)$ were nonsIUGR cases. While the umbilical artery flow pattern was normal in $59.3 \%(\mathrm{n}=16)$ of the pregnancies which developed sIUGR, $40.7 \%$ $(n=11)$ of them had abnormal umbilical artery flow pattern. The preeclampsia rate was found significantly higher in sIUGR pregnancies than non-sIUGR pregnancies $(25.9 \%$ vs. $11.1 \%, \mathrm{p}=0.042)$. The need for intensive care for both larger and smaller newborns was significantly higher in sIUGR pregnancies compared to non-sIUGR pregnancies $(\mathrm{p}<0.001)$. Three $(11.1 \%)$ of newborns in sIUGR pregnancies passed away during neonatal period. All of the newborns that passed away were the smaller newborns from sIUGR pregnancies with abnormal umbilical artery flow pattern.

Conclusion: The pregnancies with selective intrauterine growth restriction (sIUGR) are more associated with high risks in terms of perinatal outcomes compared to the pregnancies with non-sIUGR. In pregnancies developing sIUGR, the risk increases for larger fetus as well as smaller fetus. More prospective studies are needed to investigate whether this increased risk in the pregnancies with sIUGR is associated with prematurity which is more common or is a result of sIUGR.
\end{abstract}

Keywords: Monochorionic pregnancy, perinatal outcomes, selective intrauterine growth restriction.
Özet: Selektif intrauterin gelişme kısıtlıığı olan ve olmayan monokoryonik ikiz gebeliklerde perinatal sonuçların karşılaştııılması

Amaç: Selektif intrauterin gelişim kısıtlılığı (sIUGR) olan monokoryonik gebeliklerde plasentanın eşit olmayan paylaşımı ve vasküler anastomozlar sonucunda her iki fetüs olumsuz etkilenebilir. Calışmamızda sIUGR olan ve sIUGR olmayan (non-sIUGR) monokoryonik gebeliklerde hem büyük hem de küçük fetüsün perinatal sonuçlarını araştırmayı amaçladık.

Yöntem: Ocak 2013 - Ocak 2019 tarihleri arasında 196 monokoryonik ikiz gebelik retrospektif olarak incelendi. Olgular sIUGR ve non-sIUGR gebelikler olarak gruplandırıldı. sIUGR olan gebelikler ayrica normal umbilikal akım paterni olanlar ve anormal umbilikal akım paterni olanlar olarak gruplandırıldı. Gruplar arasında büyük ve küçük fetüsler için perinatal sonuçlar ayrı ayrı araştırıldı. Bulgular: Çalısmaya dahil edilen toplam 153 monokoryonik gebeliğin \%17.6's1 $(n=27)$ sIUGR gebeliklerden, \%82.4'ü $(n=126)$ non-sIUGR gebeliklerden oluşmaktaydı. sIUGR gelişen gebeliklerin \% 59.3'ünde $(\mathrm{n}=16)$ umbilikal arter akım paterni normalken, $\% 40.7$ 'sinde $(n=11)$ anormal umbilikal arter akım paterni mevcuttu. sIUGR gebeliklerde preeklampsi oranı non-sIUGR gebeliklere göre anlamlı olarak daha yüksek bulundu (\%25.9'a karş1 \%11.1, $\mathrm{p}=0.042$ ). sIUGR gebeliklerde hem büyük hem de kücük yenidoğan için yoğun bakım gereksinimi non-sIUGR gebeliklere göre anlamlı olarak daha yüksek bulundu $(\mathrm{p}<0.001)$. sIUGR gebeliklerdeki yenidoğanlardan 3 (\% 11.1) tanesi neonatal dönemde kaybedildi. Kaybedilen yenidoğanların tamamı anormal umbilikal arter akım paterni olan sIUGR gebeliklerdeki küçük yenidoğanlardı.

Sonuç: Selektif intrauterin gelişim kısıtlılı̆̆ı (sIUGR) olan gebelikler, non-sIUGR gebeliklere kıyasla perinatal sonuçlar açısından daha yüksek riskle ilişkilidir. sIUGR gelişen gebeliklerde küçük fetüsün yanı sıra büyük fetüs için de risk artısı bulunmaktadır. Artmış olan bu riskin sIUGR mevcut olan gebeliklerde daha yüksek olan prematüriteyle mi ilişkili olduğu yoksa sIUGR'nin bir sonucu mu olduğu konusunda daha fazla prospektif çalışmaya ihtiyaç vardir.

Anahtar sözcükler: Monokoryonik gebelik, perinatal sonuçlar, selektif intrauterin gelişim kısıtlılı̆̆1.

Correspondence: Münip Akalın, MD. Perinatology Clinic, Zeynep Kamil Maternity and Pediatrics Training and Research Hospital, İstanbul, Turkey. e-mail: munipakalin89@gmail.com / Received: December 9, 2020; Accepted: January 17, 2021

How to cite this article: Fide Pişirgen E, Akalın M, Demirci O, Kumru P, Akalın EE. The comparison of the perinatal outcomes in monochorionic twin pregnancies with and without selective intrauterine growth restriction. Perinatal Journal 2021;29(1):20-26. doi:10.2399/prn.21.0291004 


\section{Introduction}

Monochorionic twin pregnancies are the pregnancies where both fetuses share a single placenta. Unlike dichorionic pregnancies, monochorionic pregnancies have distinctive complications due to not sharing placenta equally and the presence of vascular anastomoses. ${ }^{[1]}$ Twin-to-twin transfusion syndrome (TTTS), selective intrauterine growth restriction (sIUGR), twin anemia polycythemia sequence (TAPS) and twin reversed arterial perfusion sequence (TRAP), which is seen more rarely, are among these complications. ${ }^{[2]}$ The root underlying cause of the complications such as TTTS, TAPS and TRAP is the placental vascular anastomoses while the root cause of sIUGR is primarily the non-equal share of placenta. ${ }^{[3,4]}$ As a result of this non-equal share, the fetus which has the most of placenta continues to develop while the development of the fetus having the smaller part of placenta falls behind. The first sign of this growth restriction may be the presence of discordance between the twins in the first trimester ultrasonography. ${ }^{[5]}$ The percentage value of difference between the crown-rump lengths of larger and smaller fetuses to the crown-rump length of larger fetus is used to investigate the presence of discordance. It has been reported that this value being more than $10 \%$ can be used for the prediction of poor fetal outcomes. ${ }^{[\sigma]}$ Besides, the diagnosis of sIUGR is established typically at the second trimester. sIUGR diagnosis is established in case that the estimated fetal weight of the one of the fetuses is below 3 rd percentile or at least two of four criteria (1- the estimated fetal weight of the smaller fetus being under 10th percentile, 2- abdominal circumference of the smaller fetus being under 10th percentile, 3 - the difference of estimated fetal weight between the fetuses being more than $25 \%$, and 4 - umbilical artery pulsatility index of the smaller fetus being more than 95th percentile) are present in the second-trimester ultrasonography. ${ }^{[1,8]}$ sIUGR is a complication seen in monochorionic pregnancies commonly, and it is present in $10-15 \%$ of all monochorionic pregnancies. ${ }^{[5]}$

Although the non-equal share of placenta is the main problem in the pathophysiology of sIUGR, vascular anastomoses which exist in the monochorionic placenta can make these pregnancies more complicated. This condition in sIUGR differs from the fetal growth restriction seen as a result of insufficient uteroplacental circulation in singleton or dichorionic pregnancies. These vascular anastomoses may significantly affect nourishment and oxygen exchange between the twins and also the hemodynamics of both fetuses. ${ }^{[9]}$ Therefore, it may be expected that the fetus with normal development is also under risk as well as the fetus with growth restriction.

In our study, we aimed to investigate the fetal and neonatal outcomes in the monochorionic pregnancies with sIUGR.

\section{Methods}

In our study, the medical records of a total of 196 women with monochorionic twin pregnancy who were followed up at the Perinatology Clinic of Zeynep Kamil Maternity and Pediatrics Training and Research Hospital between January 2013 and January 2019 were reviewed. The approval of the ethics committee of our hospital was obtained for the study (Approval date / no.: 09.01.2019 / 09). All monochorionic twin pregnancies, whose antenatal follow-ups and deliveries were done in our hospital, were included in the study. The pregnancies with missing medical records, the pregnancies that started as triple or higher multiple pregnancies but reduced to twin pregnancy by fetal reduction, the pregnancies started as monochorionic twin pregnancy but continued as singleton due to fetal loss, the pregnancies found to have chromosomal or structural anomaly in other twin, the pregnancies developing TTTS, the pregnancies developing TAPS and the pregnancies who delivered at a different center were excluded from the study. The flow chart of the cases included in and excluded from the study are shown in Fig. 1.

The medical records of 153 pregnancies and 306 fetuses and newborns included in the study were reviewed. The demographic characteristics, antenatal ultrasonography findings and Doppler indices, delivery weeks, delivery types and delivery indications of the pregnant women were recorded. sIUGR was defined as estimated fetal weight of the one of the fetuses being below 3rd percentile or the presence of at least two of four criteria (1- the estimated fetal weight of the smaller fetus being under 10th percentile, 2- abdominal circumference of the smaller fetus being under 10th percentile, 3 - the difference of estimated fetal weight between the fetuses being more than $25 \%$, and 4 - umbilical artery pulsatility index of the smaller fetus being more than 95th percentile). The cases were grouped as sIUGR and without sIUGR (non-sIUGR) pregnancies. In addition, the cases with end-diastolic forward flow in the umbilical artery were grouped as the cases with normal umbilical artery flow pattern, and the cases with end-diastolic 
flow loss or reverse flow were grouped as the cases with abnormal umbilical artery flow pattern in the pregnancies with sIUGR. The maternal complications were determined as preeclampsia, gestational diabetes mellitus (GDM) and intrahepatic cholestasis of pregnancy (ICP), and they were recorded. Birth weights, sexes, 1minute and 5-minute Apgar scores, umbilical cord $\mathrm{pH}$ and hematocrit values of the newborns, their needs for newborn intensive care unit, cranial ultrasonography findings and neonatal mortality were recorded for both newborns separately. The perinatal and neonatal outcomes of the groups developing and not developing sIUGR during antenatal follow-ups were compared.

The statistical analyses of the data were performed by using SPSS 15.0 (The Statistical Package for the Social Sciences, SPSS Inc., version 17; Chicago, IL, USA). The descriptive statistics were presented as mean \pm standard deviation and minimum-maximum values. The concordance of the variables to normal distribution was examined by visual (histogram and probability graphics) and analytic methods (Kolmogorov-Smirnov and ShapiroWilk tests). As the distribution of variables between the groups were not normal in the comparison of quantitative data, the parameters were analyzed by using MannWhitney $\mathrm{U}$ test to conduct pairwise comparisons. Chisquare test was used to compare qualitative data and Fisher's exact chi-square test in cases where test conditions could not be met. The results were determined significant where $\mathrm{p}$-value was below 0.05 .

\section{Results}

Of 196 monochorionic pregnancy in total, 172 reached 24 weeks of gestation and above. One of the twins in 6 (3.5\%) of these 172 pregnancies reaching above 24 weeks of gestation was lost in utero. Four of these 6 cases had TTTS while 2 of them had sIUGR. Both of the twin siblings lost due to sIUGR were smaller fetuses and these fetuses had abnormal umbilical artery flow pattern. The underlying reason could not be determined in one pregnancy in which both fetuses were lost. In $82.4 \%(n=126)$ of a total of 153 monochorionic pregnancies included in the study did not develop sIUGR while $17.6 \% \quad(n=27)$ had sIUGR. The mean diagnosis week of the pregnancies developing sIUGR was 22.4 (range 19-28) weeks. The demographic characteristics of monochorionic pregnancies included in the study are presented in Table 1. While $42.5 \%(n=65)$ of the pregnancies were nulliparous, $57.5 \%$ of them were multiparous. While $63.0 \%$ of the pregnancies with sIUGR were nulliparous, $38.1 \%$

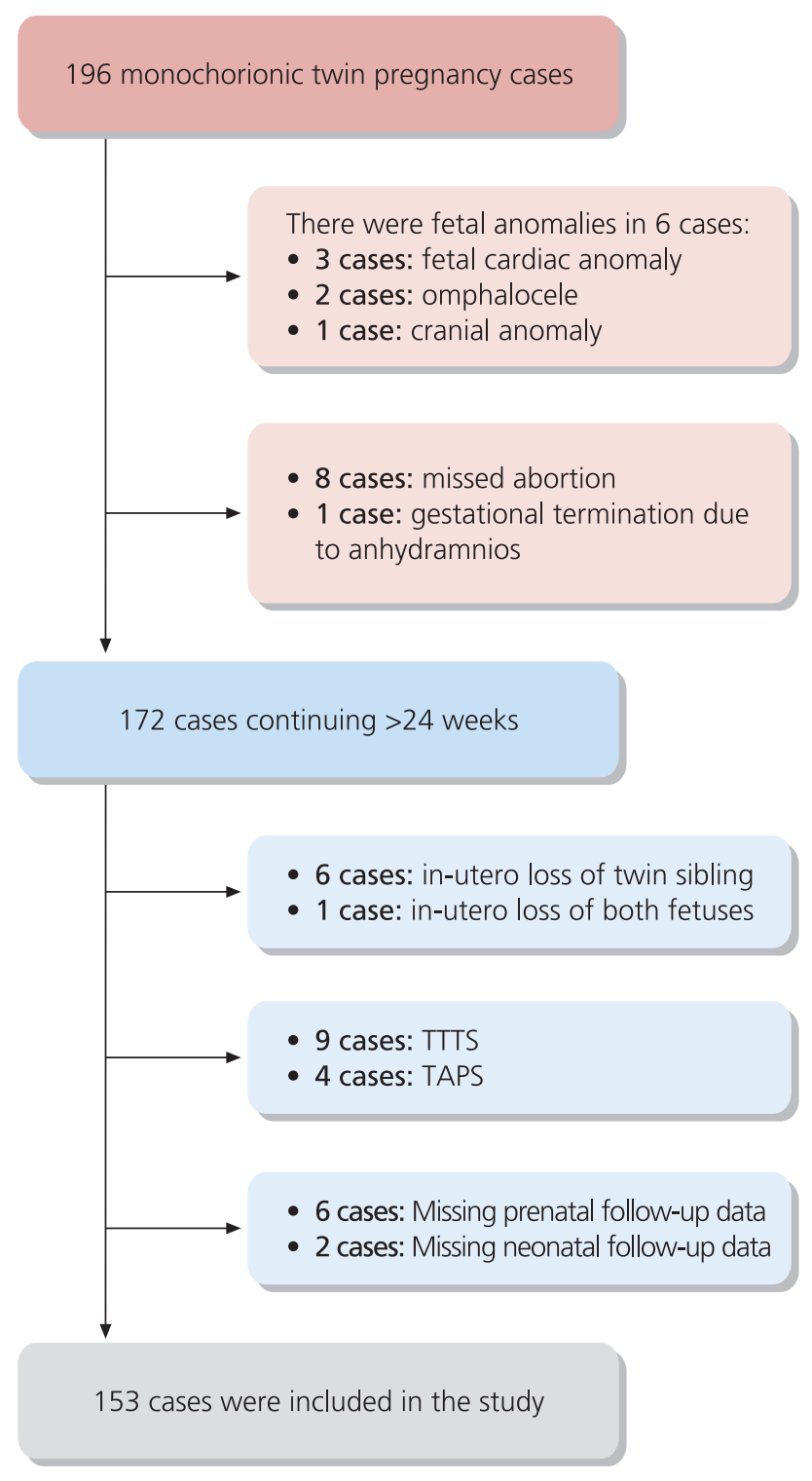

Fig. 1. The flow chart for inclusion and exclusion criteria for the cases.

of non-sIUGR pregnancies were nulliparous, and there was a significant difference between two groups $(\mathrm{p}=0.018)$. Umbilical artery flow was normal in $59.3 \%$ $(\mathrm{n}=16)$ of the pregnancies developing sIUGR during antenatal follow-ups, and $40.7 \% \quad(n=11)$ of them had abnormal umbilical artery flow pattern. On the other hand, only $1(0.8 \%)$ case had abnormal umbilical artery flow pattern in the non-sIUGR group.

The maternal complications developing during antenatal follow-ups are shown in Table 2. The preeclamp- 
Table 1. Demographic characteristics of monochorionic twin pregnancies.

\begin{tabular}{|c|c|c|c|c|c|c|c|}
\hline & \multicolumn{2}{|c|}{ All groups $(n=153)$} & \multicolumn{2}{|c|}{ Non-sIUGR $(n=126)$} & \multicolumn{2}{|c|}{ sIUGR $(n=27)$} & \multirow[b]{2}{*}{ p-value } \\
\hline & Mean \pm SD & Min-Max & Mean \pm SD & Min-Max & Mean \pm SD & Min-Max & \\
\hline Age & $28.16 \pm 5.9$ & $15-42$ & $28.02 \pm 5.85$ & $15-42$ & $28.85 \pm 6.59$ & $18-41$ & NS \\
\hline BMI & $28.89 \pm 4.19$ & $20.31-44.30$ & $29.77 \pm 4.04$ & $20.31-44.30$ & $30.43 \pm 4.89$ & $22.48-43.70$ & NS \\
\hline Gravida & $2.20 \pm 1.17$ & $1-6$ & $2.29 \pm 1.17$ & $1-6$ & $1.78 \pm 1.09$ & $1-5$ & 0.02 \\
\hline Parity & $0.89 \pm 0.95$ & $0-4$ & $0.94 \pm 0.93$ & $0-4$ & $0.63 \pm 1.00$ & $0-4$ & 0.047 \\
\hline Living & $0.86 \pm 0.92$ & $0-4$ & $0.35 \pm 0.72$ & $0-4$ & $0.15 \pm 0.36$ & $0-1$ & NS \\
\hline Abortion & $0.31 \pm 0.67$ & $0-4$ & $0.91 \pm 0.90$ & $0-4$ & $0.63 \pm 1.00$ & $0-4$ & NS \\
\hline
\end{tabular}

BMI: body mass index; non-sIUGR: without selective intrauterine growth restriction; NS: not significant; sIUGR: selective intrauterine growth restriction.

sia rate was significantly higher in the sIUGR pregnancies than non-sIUGR pregnancies $(25.9 \%$ vs. $11.1 \%$, $\mathrm{p}=0.042$ ). Although the rate of delivery by cesarean section in sIUGR pregnancies was higher than those of nonsIUGR pregnancies $(81.5 \%$ vs. $72.2 \%)$, the difference between the groups was not statistically significant $(p=0.469)$. When the reasons for delivery by cesarean section were evaluated, it was found that the rate of fetal distress in sIUGR pregnancies was significantly higher than non-sIUGR pregnancies $(\mathrm{p}<0.001)$. The weeks of delivery and newborn outcomes in sIUGR and non-sIUGR pregnancies are shown separately for larger and smaller newborns in Table 3. Birth weights and umbilical cord $\mathrm{pH}$ values of both larger and smaller newborns were lower in sIUGR pregnancies than those in non-sIUGR pregnancies. Newborns' 1-minute and 5-minute Apgar scores were lower in the smaller newborns in both sIUGR and non-sIUGR groups. There was statistically no significant difference between sIUGR and nonsIUGR pregnancies for both larger and smaller newborns in terms of the duration of hospitalization at newborn

Table 2. The maternal complications in sIUGR and non-sIUGR pregnancies.

\begin{tabular}{|c|c|c|c|c|c|c|}
\hline & & \multicolumn{2}{|c|}{$\begin{array}{c}\text { Non-sIUGR } \\
(n=126)\end{array}$} & \multicolumn{2}{|c|}{$\begin{array}{l}\text { sIUGR } \\
(n=27)\end{array}$} & \multirow[b]{2}{*}{ p-value } \\
\hline & & $\mathbf{n}$ & $\%$ & $\mathbf{n}$ & $\%$ & \\
\hline Preeclampsia & $\begin{array}{l}\text { Present } \\
\text { Absent }\end{array}$ & $\begin{array}{c}14 \\
112\end{array}$ & $\begin{array}{l}11.1 \\
88.9\end{array}$ & $\begin{array}{c}7 \\
20\end{array}$ & $\begin{array}{l}25.9 \\
74.1\end{array}$ & 0.042 \\
\hline GDM & $\begin{array}{l}\text { Present } \\
\text { Absent }\end{array}$ & $\begin{array}{c}10 \\
116\end{array}$ & $\begin{array}{c}7.9 \\
92.1\end{array}$ & $\begin{array}{c}2 \\
25\end{array}$ & $\begin{array}{l}7,4 \\
92.6\end{array}$ & NS \\
\hline ICP & $\begin{array}{l}\text { Present } \\
\text { Absent }\end{array}$ & $\begin{array}{c}5 \\
121\end{array}$ & $\begin{array}{c}4 \\
96\end{array}$ & $\begin{array}{c}0 \\
27\end{array}$ & $\begin{array}{c}0 \\
100\end{array}$ & NS \\
\hline
\end{tabular}

GDM: gestational diabetes mellitus; ICP: intrahepatic cholestasis of pregnancy; non-sIUGR: without selective intrauterine growth restriction; NS: not significant; sIUGR: selective intrauterine growth restriction. intensive care unit (NICU) (p-values were 0.200 and 0.526 , respectively). When newborn sexes were compared, there was no significant difference between sIUGR and non-sIUGR pregnancies $(\mathrm{p}=0.538)$. The need for NICU, the presence of intracranial bleeding in the cranial ultrasonography result and newborn mortality data are shown in Table 4. The need for NICU was significantly higher for both larger and smaller newborns in sIUGR pregnancies than those of non-sIUGR pregnancies. While there was no loss during neonatal period in non-sIUGR pregnancies, $3(11.1 \%)$ of the newborns in sIUGR pregnancies were lost during neonatal period. All of the newborns lost were the smaller newborns in sIUGR pregnancies with abnormal umbilical artery flow pattern.

\section{Discussion}

sIUGR is a serious complication seen in the majority of monochorionic pregnancies. Unlike dichorionic pregnancies, non-equal share of a single placenta and vascular anastomoses between the twins make the management of these pregnancies more difficult. Gratacos et al. ${ }^{[10]}$ suggested a classification involving the use of umbilical artery Doppler flow pattern of smaller fetus to overcome this management difficulty in monochorionic pregnancies developing sIUGR. In this classification, the presence of forward flow in the umbilical artery of smaller fetus was defined as Type-1 sIUGR, the presence of end-diastolic flow loss or reverse flow was defined as Type-2 sIUGR, and the presence of flow loss and reverse flow, respectively, following the forward flow in the umbilical artery was defined as Type-3 sIUGR. Type-1 sIUGR has the excellent prognosis while Type2 sIUGR has the poorest prognosis in this classification. There is unpredictable fetal prognosis in Type-3 
Table 3. The neonatal outcomes of sIUGR and non-sIUGR pregnancies.

\begin{tabular}{|c|c|c|c|c|c|c|}
\hline & & \multicolumn{2}{|c|}{ Non-sIUGR $(n=126)$} & \multicolumn{2}{|c|}{ sIUGR $(n=27)$} & \multirow[b]{2}{*}{ p-value } \\
\hline & & Mean \pm SD & Min-Max & Mean \pm SD & Min-Max & \\
\hline Week of delivery & & $35 \pm 2.61$ & $26-40$ & $33.3 \pm 2.36$ & $28-37$ & $<0.001$ \\
\hline \multirow[t]{2}{*}{ Birth weight (g) } & Larger newborn & $1985 \pm 537$ & $990-3250$ & $1900 \pm 444$ & $900-2700$ & $<0.001$ \\
\hline & Smaller newborn & $1770 \pm 441$ & $900-2750$ & $1369 \pm 394$ & $770-2150$ & $<0.001$ \\
\hline \multirow[t]{2}{*}{ Umbilical cord pH } & Larger newborn & $7.33 \pm 0.06$ & $7.05-7.45$ & $7.29 \pm 0.06$ & $7.12-7.40$ & 0.006 \\
\hline & Smaller newborn & $7.33 \pm 0.05$ & $7.2-7.42$ & $7.29 \pm 0.05$ & $7.22-7.41$ & 0.009 \\
\hline \multirow[t]{2}{*}{ Hematocrit } & Larger newborn & $48.9 \pm 9.6$ & $21-70$ & $58.5 \pm 7.4$ & $46-74$ & 0.003 \\
\hline & Smaller newborn & $46.7 \pm 8.2$ & $25-64$ & $50.2 \pm 10.6$ & $10-60$ & NS \\
\hline \multirow[t]{2}{*}{ Apgar score (1-minute) } & Larger newborn & $5.9 \pm 1.7$ & $1-8$ & $5.95 \pm 1.24$ & $4-8$ & $<0.001$ \\
\hline & Smaller newborn & $5.8 \pm 1.4$ & $2-8$ & $5.61 \pm 1.6$ & $1-8$ & $<0.001$ \\
\hline \multirow[t]{2}{*}{ Apgar score (5-minute) } & Larger newborn & $7.77 \pm 1.1$ & $4-9$ & $7.85 \pm 1.0$ & $6-9$ & 0.005 \\
\hline & Smaller newborn & $7.65 \pm 1.2$ & $4-9$ & $7.66 \pm 1.2$ & $4-9$ & 0.002 \\
\hline \multirow{2}{*}{$\begin{array}{l}\text { Need for newborn intensive } \\
\text { care period (days) }\end{array}$} & Larger newborn & $23.9 \pm 18.8$ & $3-72$ & $29.6 \pm 22.0$ & $4-63$ & NS \\
\hline & Smaller newborn & $25.7 \pm 21.7$ & $3-86$ & $26.6 \pm 20.4$ & $1-70$ & NS \\
\hline
\end{tabular}

non-sIUGR: without selective intrauterine growth restriction; NS: not significant; sIUGR: selective intrauterine growth restriction.

sIUGR. We classified umbilical artery flow patterns as normal and abnormal as there were no Type-3 sIUGR pregnancy in our study. The umbilical artery flow pattern was normal in $59.3 \%(\mathrm{n}=16)$ of the pregnancies developing sIUGR and abnormal in $40.7 \%(n=11)$ of them in our study. We found abnormal umbilical artery flow pattern in the smaller fetus in 2 sIUGR cases lost in utero. In addition, we observed that 3 newborns lost during neonatal period were those with abnormal umbilical artery flow pattern in sIUGR group. Therefore, we believe that the presence of flow loss in the umbilical artery of smaller fetus in particular during antenatal follow-up of sIUGR pregnancies is important.

Buca et al. ${ }^{[1]}$ analyzed mortality risk in smaller and larger twins separately in their meta-analysis conduct on the pregnancies with sIUGR. In their meta-analysis, the perinatal mortality was significantly higher in the smaller fetus in Type-2 sIUGR compared to the larger fetus

Table 4. The need for newborn intensive care, intracranial bleeding and neonatal mortality in sIUGR and non-sIUGR pregnancies.

\begin{tabular}{|c|c|c|c|c|c|c|c|}
\hline & & & \multicolumn{2}{|c|}{ Non-sIUGR $(n=126)$} & \multicolumn{2}{|c|}{ sIUGR (n=27) } & \multirow[b]{2}{*}{ p-value } \\
\hline & & & $\mathbf{n}$ & $\%$ & $\mathbf{n}$ & $\%$ & \\
\hline \multirow{4}{*}{$\begin{array}{l}\text { Need for newborn } \\
\text { intensive care }\end{array}$} & Larger newborn & Absent & 72 & 57.1 & 3 & 11.1 & $<0.001$ \\
\hline & & Present & 54 & 42.9 & 24 & 88.9 & \\
\hline & Smaller newborn & Absent & 68 & 54 & 3 & 11.1 & $<0.001$ \\
\hline & & Present & 58 & 46 & 24 & 88.9 & \\
\hline \multirow[t]{4}{*}{ Intracranial bleeding } & Larger newborn & Absent & 33 & 89.2 & 22 & 100 & NS \\
\hline & & Present & 3 & 8.1 & 0 & 0 & \\
\hline & Smaller newborn & Absent & 39 & 90.7 & 17 & 89.5 & NS \\
\hline & & Present & 4 & 9.3 & 2 & 10.5 & \\
\hline \multirow[t]{4}{*}{ Neonatal mortality } & Larger newborn & Absent & 126 & 100 & 27 & 100 & NS \\
\hline & & Present & 0 & 0 & 0 & 0 & \\
\hline & Smaller newborn & Absent & 126 & 100 & 24 & 88.9 & 0.005 \\
\hline & & Present & 0 & 0 & 3 & 11.1 & \\
\hline
\end{tabular}

non-sIUGR: without selective intrauterine growth restriction; NS: not significant; sIUGR: selective intrauterine growth restriction. 
$(\mathrm{OR}=2.4 ; 95 \% \mathrm{CI}=1.3-4.4)$. In addition, there was no significant difference in the perinatal mortality rates for larger and smaller twins in Type- 1 and Type-3 sIUGR in the results of the meta-analysis. Similar to the results of our study, the findings obtained in this systematic review showed that the monochorionic twin pregnancies affected by Type-2 sIUGR had higher rates of perinatal mortality and morbidity than those with Type-1 sIUGR. This meta-analysis also indicates that the probability of an abnormal result is usually not significantly different between Type-2 and Type-3 sIUGR cases. In our study, we did not make this evaluation as there were no Type-3 sIUGR cases.

When we reviewed the demographic characteristics of sIUGR and non-sIUGR pregnancies, we found higher nulliparity rates in sIUGR pregnancies $(63.0 \%$ vs. $38.1 \%)$. Advanced maternal age, low body mass index (BMI) and nulliparity are among the risk factors for fetal growth restriction in singleton pregnancies. ${ }^{[12]}$ While advanced maternal age and low BMI did not seem to be risk factors for sIUGR in our study, we found that nulliparity was a risk factor for sIUGR in monochorionic pregnancies like in singleton pregnancies. We did not find any difference between non-sIUGR and sIUGR pregnancies in terms of GDM and ICP in our study. The frequency of preeclampsia was higher in sIUGR pregnancies. It is known that preeclampsia is seen more frequently in multiple pregnancies. ${ }^{[13]}$ The increase in placental mass and immunological load is held responsible for this frequency. Besides, it is not thought that zygosity and chorionicity have an impact on the preeclampsia risk in twin pregnancy. ${ }^{[14]}$ Preeclampsia rate was higher in sIUGR pregnancies in our study. The underlying pathophysiology of fetal growth restriction developing on the basis of preeclampsia is the insufficient uteroplacental flow developing as a result of defective invasion of spiral arteries by trophoblasts. ${ }^{[15]}$ It is considered that preeclampsia may have a role in the development of sIUGR in monochorionic pregnancies. In addition to the non-equal placental share in monochorionic pregnancies, the presence of defective artery invasion may be responsible for intensifying the growth restriction in the fetus which has smaller share of placenta.

Weisz et al. ${ }^{[16]}$ compared the neonatal results of sIUGR and non-sIUGR pregnancies in their study and found that sIUGR pregnancies with abnormal umbilical artery Doppler flow had significantly more neonatal complications. However, the authors did not group newborns into smaller and larger newborns. The association between smaller newborn in sIUGR pregnancies and poor neonatal outcomes is a predictable result. In our study, we found that larger newborns were also associated with poor neonatal outcomes similar to smaller newborns. On the other hand, mean week of delivery was 35 in non-sIUGR pregnancies in our study while it was 33 weeks in sIUGR pregnancies. The association between prematurity and poor neonatal outcomes is well-known. Therefore, it remains uncertain that if this increased risk of poor neonatal outcome is associated with prematurity which is higher in pregnancies with sIUGR or non-equal placental share in sIUGR. Lopriore et al. ${ }^{[17]}$ conducted a study on discordant monochorionic twins to compare larger newborns with smaller newborns, and concluded that the neonatal morbidity risk increased. However, they did not make any compare in non-discordant twin pregnancies. We believe that comparing smaller and larger newborns in pregnancies with sIUGR and non-sIUGR separately is important to obtain more accurate results.

We found higher cesarean section rates in pregnancies with sIUGR ( $81.5 \%$ vs. $72.2 \%$ ). We believe that the presence of higher rates of umbilical artery Doppler abnormality in the pregnancies with sIUGR and the presence of higher rates of fetal distress in the pregnancies with sIUGR lead to this difference. When we compared sIUGR and non-sIUGR pregnancies for neonatal mortality, we found significantly high rates of neonatal mortality in smaller fetuses. However, it is unclear if mortality rates are more associated with the complications due to growth restriction and non-equal placental share or with the prematurity. Nonetheless, the fact that all 3 neonatal deaths occurred in the smaller fetuses of sIUGR pregnancies makes us to consider that these pregnancies should be monitored more closely. There was no significant difference in terms of intracranial bleeding in sIUGR pregnancies for both larger and smaller newborns in our study. Weisz et al. ${ }^{[16]}$ found in their study that the rates of intracranial anomalies are higher in the smaller newborns with abnormal umbilical artery flow pattern in pregnancies developing sIUGR. We found high rates of intracranial bleeding in the smaller newborns both in sIUGR and non-sIUGR groups in our study; however, there was no statistically significant difference between the groups.

\section{Conclusion}

The pregnancies with selective intrauterine growth restriction are associated with higher risks of poor fetal and neonatal outcomes compared to the pregnancies 
with non-sIUGR. In pregnancies developing sIUGR, larger fetuses are also under risk as well as smaller fetuses. More prospective studies are needed to investigate whether this increased risk is associated with prematurity or is a result of sIUGR.

Funding: This work did not receive any specific grant from funding agencies in the public, commercial, or not-for-profit sectors.

Compliance with Ethical Standards: The authors stated that the standards regarding research and publication ethics, the Personal Data Protection Law and the copyright regulations applicable to intellectual and artistic works are complied with and there is no conflict of interest.

\section{References}

1. Weiner E, Barber E, Feldstein O, Dekalo A, Schreiber L, Bar J, et al. Placental histopathology differences and neonatal outcome in dichorionic-diamniotic as compared to monochorionic-diamniotic twin pregnancies. Reprod Sci 2018;25:1067-72. [PubMed] [CrossRef]

2. Lewi L, Gucciardo L, Van Mieghem T, de Koninck P, Beck $\mathrm{V}$, Medek H, et al. Monochorionic diamniotic twin pregnancies: natural history and risk stratification. Fetal Diagn Ther 2010;27:121-33. [PubMed] [CrossRef]

3. Fick AL, Feldstein VA, Norton ME, Wassel Fyr C, Caughey $\mathrm{AB}$, Machin GA. Unequal placental sharing and birth weight discordance in monochorionic diamniotic twins. Am J Obstet Gynecol 2006;195:178-83. [PubMed] [CrossRef]

4. Denbow ML, Cox P, Taylor M, Hammal DM, Fisk NM. Placental angioarchitecture in monochorionic twin pregnancies: relationship to fetal growth, fetofetal transfusion syndrome, and pregnancy outcome. Am J Obstet Gynecol 2000; 182:417-26. [PubMed] [CrossRef]

5. Memmo A, Dias T, Mahsud-Dornan S, Papageorghiou AT, Bhide A, Thilaganathan B. Prediction of selective fetal growth restriction and twin-to-twin transfusion syndrome in monochorionic twins. BJOG 2012;119:417-21. [PubMed] [CrossRef]

6. D'Antonio F, Khalil A, Pagani G, Papageorghiou AT, Bhide A, Thilaganathan B. Crown-rump length discordance and adverse perinatal outcome in twin pregnancies: systematic review and meta-analysis. Ultrasound Obstet Gynecol 2014;44:138-46. [PubMed] [CrossRef]

7. Khalil A, Rodgers M, Baschat A, Bhide A, Gratacos E, Hecher K, et al. ISUOG Practice Guidelines: role of ultrasound in twin pregnancy. Ultrasound Obstet Gynecol 2016; 47:247-63. [PubMed] [CrossRef]
8. Khalil A, Beune I, Hecher K, Wynia K, Ganzevoort W, Reed $\mathrm{K}$, et al. Consensus definition and essential reporting parameters of selective fetal growth restriction in twin pregnancy: a Delphi procedure. Ultrasound Obstet Gynecol 2019;53:4754. [PubMed] [CrossRef]

9. Lewi L, Cannie M, Blickstein I, Jani J, Huber A, Hecher K, et al. Placental sharing, birthweight discordance, and vascular anastomoses in monochorionic diamniotic twin placentas. Am J Obstet Gynecol 2007;197:587.e1-8. [PubMed] [CrossRef]

10. Gratacós E, Lewi L, Muñoz B, Acosta-Rojas R, HernandezAndrade E, Martinez JM, et al. A classification system for selective intrauterine growth restriction in monochorionic pregnancies according to umbilical artery Doppler flow in the smaller twin. Ultrasound Obstet Gynecol 2007;30:2834. [PubMed] [CrossRef]

11. Buca D, Pagani G, Rizzo G, Familiari A, Flacco ME, Manzoli $\mathrm{L}$, et al. Outcome of monochorionic twin pregnancy with selective intrauterine growth restriction according to umbilical artery Doppler flow pattern of smaller twin: systematic review and meta-analysis. Ultrasound Obstet Gynecol 2017;50:55968. [PubMed] [CrossRef]

12. Cunningham FG, Leveno KJ, Bloom SL, Hauth JC, Gilstrap III LC, Wenstrom KD (editors). Williams obstetrics. 22nd ed. Chapter 38: Fetal growth disorders. New York, NY: McGraw Hill; 2001. pp. 893-910.

13. Francisco C, Wright D, BenkCE Z, Syngelaki A, Nicolaides $\mathrm{KH}$. Hidden high rate of pre-eclampsia in twin compared with singleton pregnancy. Ultrasound Obstet Gynecol 2017;50: 88-92. [PubMed] [CrossRef]

14. Lučovnik M, Blickstein I, Lasič M, Fabjan-Vodušek V, BržanSimenc G, Verdenik I, et al. Hypertensive disorders during monozygotic and dizygotic twin gestations: a populationbased study. Hypertens Pregnancy 2016;35:542-7. [PubMed] [CrossRef]

15. Lim KH, Zhou Y, Janatpour M, McMaster M, Bass K, Chun $\mathrm{SH}$, et al. Human cytotrophoblast differentiation/invasion is abnormal in pre-eclampsia. Am J Pathol 1997;151:1809-18. [PubMed]

16. Weisz B, Hogen L, Yinon Y, Gindes L, Shrim A, Simchen M, et al. Perinatal outcome of monochorionic twins with selective IUGR compared with uncomplicated monochorionic twins. Twin Res Hum Genet 2011;14:457-62. [PubMed] [CrossRef]

17. Lopriore E, Sluimers C, Pasman SA, Middeldorp JM, Oepkes D, Walther FJ. Neonatal morbidity in growth-discordant monochorionic twins: comparison between the larger and the smaller twin. Twin Res Hum Genet 2012;15:5416. [PubMed] [CrossRef]

This work is licensed under the Creative Commons Attribution-NonCommercial-NoDerivs 4.0 Unported (CC BY-NC-ND4.0) License. To view a copy of this license, visit http://creativecommons.org/licenses/by-nc-nd/4.0/ or send a letter to Creative Commons, PO Box 1866, Mountain View, CA 94042 , USA

Publisher's Note: The content of this publication does not necessarily reflect the views or policies of the publisher, nor does any mention of trade names, commercial products, or organizations imply endorsement by the publisher. Scientific and legal responsibilities of published manuscript belong to their author(s). The publisher remains neutral with regard to jurisdictional claims in published maps and institutional affiliations. 